\title{
Review \\ Pathogenesis of the Pseudomonas aeruginosa Biofilm: A Review
}

\author{
Felipe Francisco Tuon *, Leticia Ramos Dantas, Paula Hansen Suss (D) and Victoria Stadler Tasca Ribeiro
}

check for updates

Citation: Tuon, F.F.; Dantas, L.R.; Suss, P.H.; Tasca Ribeiro, V.S.

Pathogenesis of the Pseudomonas aeruginosa Biofilm: A Review.

Pathogens 2022, 11, 300. https://

doi.org/10.3390/pathogens11030300

Academic Editors: Natalia Kirienko and Carolyn Cannon

Received: 22 December 2021

Accepted: 24 February 2022

Published: 27 February 2022

Publisher's Note: MDPI stays neutral with regard to jurisdictional claims in published maps and institutional affiliations.

Copyright: (C) 2022 by the authors. Licensee MDPI, Basel, Switzerland. This article is an open access article distributed under the terms and conditions of the Creative Commons Attribution (CC BY) license (https:// creativecommons.org/licenses/by/ $4.0 /)$.

\author{
Laboratory of Emerging Infectious Diseases, School of Medicine, Pontifícia Universidade Católica do Paraná, \\ Curitiba 80215-901, Brazil; leticia.dantas@pucpr.br (L.R.D.); paula.h@pucpr.br (P.H.S.); \\ vicstadler@gmail.com (V.S.T.R.) \\ * Correspondence: felipe.tuon@pucpr.br or flptuon@gmail.com; Tel.: +55-(41)-3271-2247
}

\begin{abstract}
Pseudomonas aeruginosa is associated with several human infections, mainly related to healthcare services. In the hospital, it is associated with resistance to several antibiotics, which poses a great challenge to therapy. However, one of the biggest challenges in treating $P$. aeruginosa infections is that related to biofilms. The complex structure of the P. aeruginosa biofilm contributes an additional factor to the pathogenicity of this microorganism, leading to therapeutic failure, in addition to escape from the immune system, and generating chronic infections that are difficult to eradicate. In this review, we address several molecular aspects of the pathogenicity of $P$. aeruginosa biofilms.
\end{abstract}

Keywords: Pseudomonas aeruginosa; biofilm; quorum sensing; virulence

\section{Introduction}

Biofilms are the underlying cause of a variety of tissue- and implant-associated infections. Infections associated with biofilms encompass tooth caries, periodontitis, otitis media, chronic sinusitis, chronic wound changes, musculoskeletal infections (osteomyelitis), biliary tract infection, bacterial prostatitis, native valve endocarditis, and medical device-related infections. Pseudomonas aeruginosa is considered a model organism for studying biofilm formation and is the most studied microorganism with regard to quorum sensing (QS). In this section, we describe the pathogenicity of the $P$. aeruginosa biofilm, including its characteristics and QS properties.

\section{Pseudomonas aeruginosa Characteristics}

Pseudomonas aeruginosa is a Gram-negative aerobic rod-shaped bacterium that can be isolated from most environments, including soil, plants, and mammal tissue [1]. This bacterium can survive on water, different surfaces, and medical devices using its influential binding factors, such as flagella, pili, and biofilms. Hence, P. aeruginosa is abundant in natural and artificial environments, including lakes, hospitals, and household sink drains [2].

Pseudomonas aeruginosa is an opportunistic pathogen that causes several infections in humans (Figure 1). It has become an important cause of nosocomial infections and antibiotic resistance $[3,4]$. Pseudomonas aeruginosa can be specified as one of the opportunistic bacteria related to healthcare infections, including ventilator-associated pneumonia (VAP), intensive care unit infections, central line-related blood stream infections, surgical site infections, urinary tract infections, burn wound infections, keratitis, and otitis media [5-8]. Pseudomonas aeruginosa is an organism capable of adapting to changes in the environment, rapidly developing resistance to antibiotics, and producing a variety of virulence factors.

This pathogen can affect immunocompromised patients, in part due to its ability to evade both innate and acquired immune defenses through adhesion, colonization, and biofilm formation and to produce various virulence factors that cause significant tissue damage [9]. It also causes diseases with a high mortality rate in patients diagnosed with cystic fibrosis, neonatal infections, cancer, and severe burns [9,10]. 


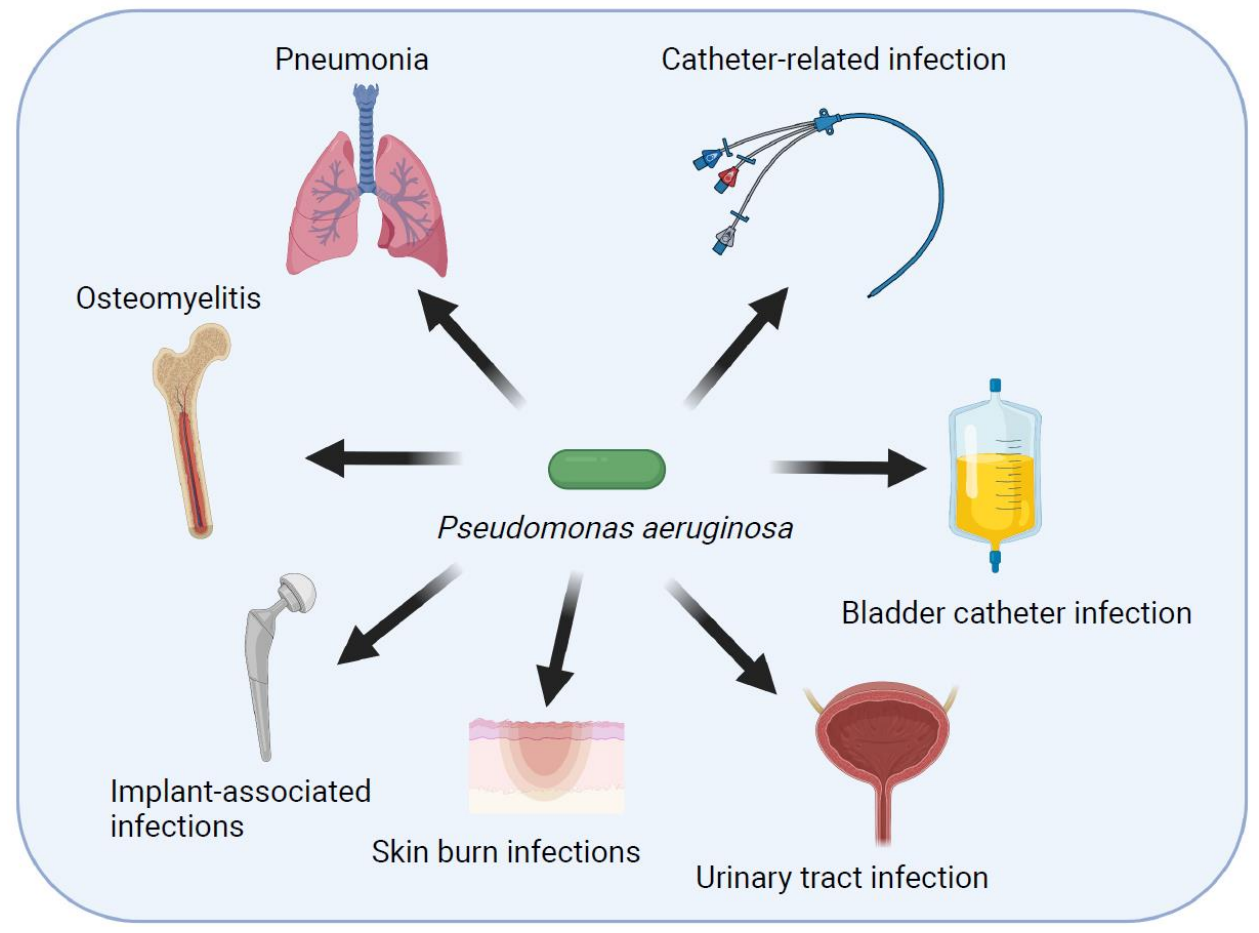

Figure 1. Schematic representation of main infections caused by Pseudomonas aeruginosa.

Infections caused by P. aeruginosa can be life-threatening when inadequate therapy is employed, particularly when multidrug-resistant (MDR) strains are involved [11-14]. Multidrug resistance has been a threat to human and animal health for the last 30 years. Furthermore, P. aeruginosa is one of the most prevalent pathogens in hospital environments, causing more than $50 \%$ of healthcare-acquired infections [15]. Even though new antimicrobial drugs have been developed, the mortality rates due to P. aeruginosa remain high, in the range of $20-60 \%[5,8,12-14,16]$.

The major risk factors for P. aeruginosa infections are structural lung diseases, hematological neoplasms, transplantation, skin burns, recent use of antibiotics, presence of implants, prolonged hospitalization, and mechanical ventilation [17].

Considering the pathogenesis of P. aeruginosa infections, biofilm production is one of the most important virulence determinants. Pseudomonas aeruginosa is a well-known biofilm producer, making it an interesting in vitro model to understand biofilm formation [18]. Pseudomonas aeruginosa also colonizes several different surfaces, including medical materials and food industry equipment, and form biofilms, leading to chronic infections owing to increased resistance to antibiotics, various irradiation treatments, environmental conditions, disinfectants, and the immune system $[19,20]$.

\section{Pseudomonas aeruginosa Biofilms}

Two distinct lifestyles, planktonic and sessile cells, can be adopted by P. aeruginosa. The planktonic state can be encountered in a liquid culture suspension, whereas on natural or synthetic surfaces, P. aeruginosa can form sticky clusters in permanent rearrangements characterized by the secretion of an adhesive and protective matrix [21]. Defined as a "biofilm," this bacterial community adhering to a surface appears as an adaptive response to an environment more or less unsuited to growth in planktonic form [22].

Biofilms are dense aggregations of cells that produce extracellular matrix components that hold the community together. The biofilm mode of growth allows cells to stay close to nutrients, promotes the exchange of genetic material, and protects cells from a variety of chemical and environmental stresses, including engulfment by phagocytes [23]. A biofilm is composed of a self-secreted matrix made up of proteins $(<2 \%)$, DNA $(<1 \%)$, polysaccharides $(1-2 \%)$, and RNA $(<1 \%)$, with water as the remainder $(97 \%)$. Alginate, Psl, and Pel are 
the three exopolysaccharides responsible for the main components in the biofilm matrix. They carry out several biological functions, especially with respect to the protection of the bacterial cell from antibiotics and the human immune system [24].

Bacterial biofilm has been evaluated for exhibiting phenotypic heterogeneity due to chemical variation within the biofilm, including oxygen gradients [25], nutrient fluctuations [26], and $\mathrm{pH}$ changes [27]. These environmental conditions are detected by individual bacterial cells, leading to metabolic activity and differential gene expression, even within a genetically homogeneous population [28]. Biofilms are approximately 10-1000 times more resistant to antibiotics than planktonic cells. This is due to the lack of antibiotic penetration into the complex polysaccharide matrix, as well as modification of the metabolic activity and protein synthesis $[29,30]$.

Bacteria that grow in biofilms often exhibit a variety of phenotypic differences compared with the same strains grown in planktonic culture. These differences include changes in mobility, in some cases increases in the production of extracellular polysaccharides, and increased resistance to antibiotics [31,32]. Studies using DNA microarray analysis have revealed differences in the expression of more than 70 genes of $P$. aeruginosa following five days of biofilm growth [33]. Proteomic analysis revealed an almost $50 \%$ change in protein profiles following attachment of $P$. aeruginosa to an inorganic surface before developing a biofilm [34].

Considering all these aspects, for infections caused by biofilm-forming P. aeruginosa, such as in cystic fibrosis, the eradication of the pathogen is almost impossible, and additional challenges are encountered when treating infections caused by MDR strains [35]. These complications increase patient morbidity and mortality. Higher costs of treatment as well as greater frequencies and longer periods of hospitalization are other outcomes $[19,36]$. Macrophages exposed to biofilms exhibit secretory properties, and thus transform into cells responsible for tissue injury, even without direct contact with bacteria [37].

A greater understanding of the biofilm structure and composition, including the molecular mechanisms, and antimicrobial tolerance within the biofilm is important for the design of strategies to prevent, manage, and eradicate biofilm-associated infections.

\section{Biofilm Structure and Dynamics}

Alginate is an exopolysaccharide and one of the major components of the biofilm in mucoid strains of P. aeruginosa. The high molecular weight of this molecule is composed of D-mannuronic and L-guluronic acids, $\beta 1-4$ linked and O-acetylated. These enzymes are coded by algD operon for alginate synthesis; their expression is regulated by $\mathrm{AlgT}$ $\sigma$-factor [38]. Alginate is overproduced by mucoid P. aeruginosa strains, and despite not being necessary for biofilm formation, is important in its maturation and stability [18,39,40].

Alginate attaches to mucin found in the respiratory tract, acting as an adhesin, and its acetyl groups increase the viscosity, which accumulate water and nutrients in the biofilm [38]. Alginate also contributes to persistence of the bacterium by protecting $P$. aeruginosa against phagocytosis and scavenging radical oxygen species released by activated macrophages [41]. Furthermore, alginate elicit a strong leukocyte response, the release of radical oxygen species, which contributes to lung inflammation [42]. Another important property of alginate is its ability to bind aminoglycoside antibiotics, impairing their penetration into the biofilm, which enhances the resistance against antibiotics as well as clinical therapeutic failure [43].

Rhamnolipids are amphipathic molecules found in the extracellular environment. They are secondary metabolites formed by a rhamnose linked via a dimer of a $\beta$-hydroxy fatty acid bond to O-glycosidic. These molecules have the ability to degrade the lung surfactant [44], decreasing the transepithelial electrical resistance, leading to the disruption of tight junctions of respiratory cells $[45,46]$.

This condition promotes the colonization of the airways by P. aeruginosa, increasing the chance of pneumonia [47]. Rhamnolipids contribute to biofilm architecture by keeping the non-colonized channels open [48] (see Figure 2D). Rhamnolipids facilitate sliding 
motility in the absence of flagella and enable swarming motility by decreasing the surface tension, owing to their surfactant properties [49-51]. Iron-restricted conditions induce the production of rhamnolipids, promoting twitching motility [52]. Host innate immunity can be suppressed by blocking flagellin-induced human $\beta$-defensin 2 [53].

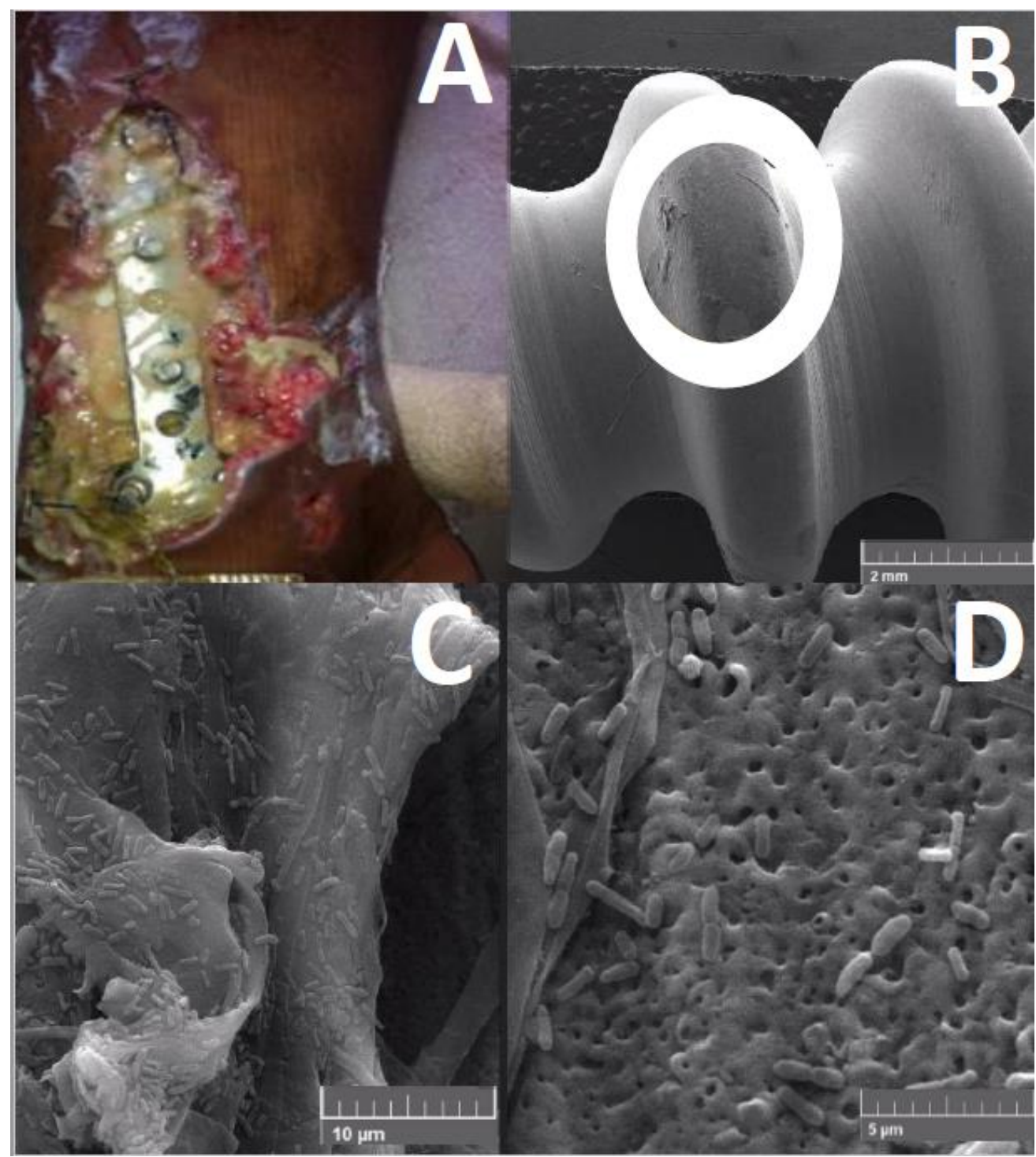

Figure 2. Biofilm formed by Pseudomonas aeruginosa on an orthopedical device. (A) - Clinical infection after exposure tibial fracture; (B) - Biofilm identification using scanning electronic microscopy in the orthopedic screw of the same patient; (C,D) - P. aeruginosa biofilm in the surgical screw under greater magnifications. Source: authors.

\section{Regulation Systems Involved in Pseudomonas aeruginosa Biofilm Formation}

The communication of bacterial cells has been shown to be important for the development of $P$. aeruginosa biofilms [54]. The virulence genes in $P$. aeruginosa are modulated by a bacterial cell-to-cell signaling mechanism, known as QS [55]. QS bacteria produce small signaling molecules that at a high population density can interact with associated receptors. This interaction induces the expression of various genes related to biofilm production and bacterial virulence [55]. QS plays a pivotal role in the pathogenesis of P. aeruginosa, beginning with host colonization to invasion, infection, dissemination, immune evasion, and drug resistance [56].

The four most important interconnected systems of QS in P. aeruginosa are termed Las, Rhl, Pqs, and Iqs. These hierarchical network systems enable crosstalk between multiple 
cellular signals through QS. The LasR/LasI and RhlR/RhlI QS systems regulate synthesis and signal transduction via 3-oxo-C12-HSL and C4-HSL, respectively. LasI synthesizes 3-oxoC12-HSL, which activates the cytoplasmic receptor. LasR regulates the expression of hemolysins, proteases, elastases, and exotoxin-A production genes for biofilm formation [57]. LasR in P. aeruginosa was identified to be a key regulator in the expression of the lasB gene, which encodes for a metalloprotease elastase [58]. Subsequently, LasR was shown to be necessary for the transcription of apr $A$, las $A$, and tox $A$. Hence, it is considered a global regulator of the virulence genes in $P$. aeruginosa [59].

The chemical structure of this gene-mediated Pseudomonas autoinducer (PAI) was recently characterized as that of $\mathrm{N}$-(3-oxododecanoyl)-homoserine lactone (OdDHL) [60]. In $P$. aeruginosa, the LasR protein is required for the activation of las $B$ and several other virulence genes. The PAI produced by the bacteria is required for the activity of LasR. Another autoinducer, structurally identified to be N-butyrylhomoserine lactone (BHL), has been discovered [61]. BHL does not interact with LasR protein directly to activate lasB gene expression [60]. RhlR, a regulatory protein encoded by the rhamnolipid synthase gene cluster rhlABR, is the cognate receptor of BHL [62].

The third QS signal, 2-heptyl-3-hydroxy-4-quinolone, also called Pseudomonas quinolone signal (PQS), is associated with lasB expression in a lasR mutant of P. aeruginosa, and cannot be mimicked by OdDHL or BHL [63].

The fourth intercellular communication signal named as Iqs belongs to a new class of QS signal molecules. The genes involved in Iqs synthesis form a non-ribosomal peptide synthase gene cluster, ambBCDE [64]. When disrupted, it causes a decrease in the production of PQS as well as BHL signals. The same pathway induces the expression of virulence factors such as pyocyanin, rhamnolipids, and elastase.

The QS circuits in P. aeruginosa are complex. The Las system, activated by OdDHL, promotes LasR-OdDHL complex multimerization and consequently activates the transcription of rhlR, rhlI, lasI, and other virulence genes [65-67]. The RhlR-BHL complex also activates the expression of its own regulon and RhlI, forming a second positive feedback loop. LasR-OdDHL also positively regulates PqsR, the transcriptional regulator of the PQS biosynthesis operon $p q s A B C D$ [68]. PQS, in turn, was found to be able to enhance the transcription of RhlI, thus influencing BHL production and the overall expression of the Rhl QS system and indirectly modulating the Rhl-dependent phenotypes [69] (Figure 3).

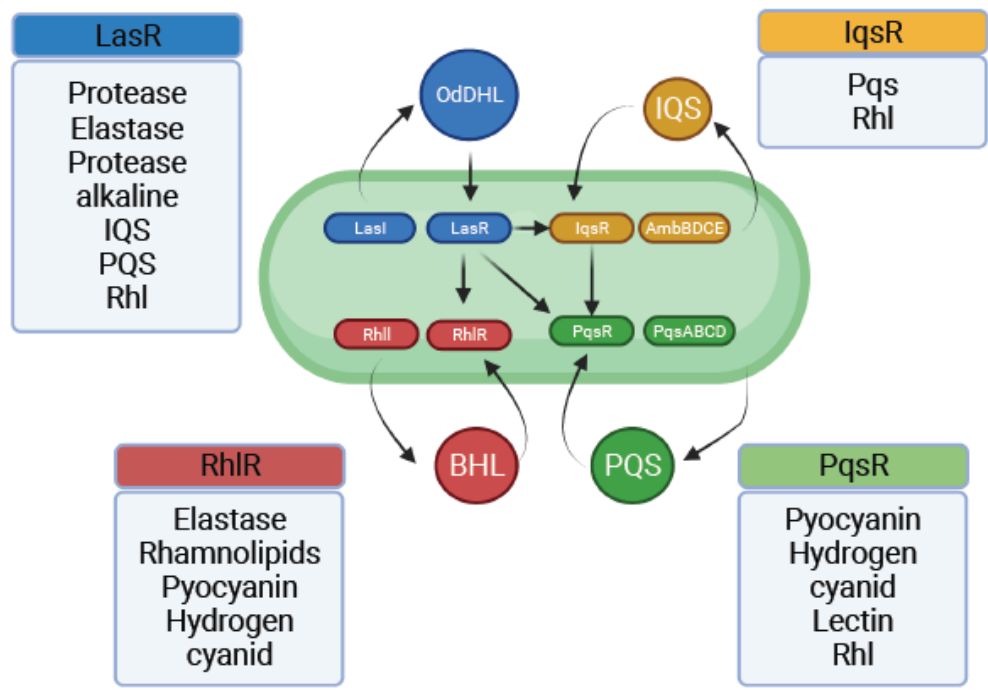

Figure 3. Genes of the quorum sensing systems of Pseudomonas aeruginosa with regulatory looping and molecules associated with biofilms and pathogenicity.

Pseudomonas aeruginosa invades hosts with a local or systemic immune system deficit or attenuated epithelial barrier in a passive manner. However, an outer-membrane pro- 
tein, OprF, can recognize and bind to IFN- $\gamma$, activating the Rhl QS system. This pathway enhances the expression of lecA and the production of its encoded virulence protein, galactophilic lectin. Pyocyanin is another virulence factor that is upregulated in the presence of IFN- $\gamma$ [70]. Human dynorphin is an endogenous k-receptor agonist that can penetrate the bacterial membrane and potentially induce the expression of PqsR and PqsABCDE, increasing the biosynthesis of PQS and HHQ [71].

C-type natriuretic peptide (CNP), which is produced by endothelial cells, is also involved in the regulation of $P$. aeruginosa QS, inducing a rise in intracellular cAMP concentrations, which leads to the activation of the global virulence activator Vfr [72].

The stationary-phase sigma factor RpoS is involved in the control of biofilm growth in P. aeruginosa [73]. Approximately 700 genes, most of them related to QS, are under direct or indirect control of RpoS [74]. Bouillet et al. (2019) demonstrated that the post-translational regulation of RpoS depends on the HsbR-HsbA partner-switch. This system is connected to the FlgM-HsbA partner-switch, triggering the release or sequestration of RpoS. This mechanism is likely the most efficient system this bacterium has found to decide to swim or to form and disperse its biofilm [75].

More recently, PQS has been implicated in the first stages of biofilm development. It functions as an outer membrane vesicle (OMV) inducer that contributes at multiple stages. It has been demonstrated that PQS and OMVs are differentially produced during P. aeruginosa biofilm development, providing evidence that effective biofilm dispersion is dependent on the production of PQS-induced OMVs [76]. It is interesting that these genes involved in QS constitute nearly $10 \%$ of the P. aeruginosa genome and therefore account for a majority of the physiological processes and virulence phenotypes [77].

\section{Mechanisms of Virulence in Pseudomonas aeruginosa}

In general, $P$. aeruginosa adopts a sessile lifestyle during chronic infections or a planktonic lifestyle for acute infections. Several other mechanisms of virulence in P. aeruginosa, including motility (flagella and pili), immune evasion (elastase and alkaline protease), antibiotic resistance (pump efflux and modifying enzymes), cytotoxicity (hydrogen cyanide (HCN), exotoxin A, T3SS, and pyocyanin), iron scavenging (proteases and siderophores), and finally biofilm structure and dynamics (alginate and rhamnolipids), have been described [78] (Table 1).

Table 1. Virulence mechanisms employed during Pseudomonas aeruginosa infections.

\begin{tabular}{|c|c|c|}
\hline \multirow{2}{*}{ Antibiotic resistance } & Efflux pumps & \\
\hline & Modifying enzymes & \\
\hline \multirow{2}{*}{ Motility } & flagella & \\
\hline & Type IV pili & \\
\hline \multirow{2}{*}{ Biofilm structure \& dynamics } & Rhamnolipids & \\
\hline & alginate & \\
\hline \multirow{3}{*}{ Iron scavenging } & proteases & \\
\hline & \multirow{2}{*}{ siderophores } & pyochelin \\
\hline & & pyoverdine \\
\hline \multirow{4}{*}{ Cytotoxicity } & pyocyanin & \\
\hline & T3SS & \\
\hline & Endotoxin A & \\
\hline & $\mathrm{HCN}$ & \\
\hline \multirow{2}{*}{ Immune evasion } & elastase & \\
\hline & Alkaline protease & \\
\hline
\end{tabular}


Pseudomonas aeruginosa encodes virulence factors that increase its fitness and chances of survival within a human host. These virulence factors promote bacterial growth and survival, maneuvering the host cellular machinery by causing devastating injuries, tissue necrosis, evasion, and immune system impairment [79].

\section{Motility (Flagella and Type IV Pili)}

Flagella are essential for P. aeruginosa initial attachment to surfaces. Twitching motility has been necessary for normal biofilm development after microcolony formation [80]. The flagellum is also responsible for P. aeruginosa swimming motility in low-viscosity environments. This process occurs through rotation, producing a force moving the bacterium forward [81]. Flagellar attachment is important in initial biofilm establishment, whereas the motility mechanism is associated with dispersal in the final biofilm steps. Robust biofilms during the maturation stage requires an adequate timing of motility control [82].

Twitching motility depends on type IV pili, which play an important role in mediating adherence to mucosal surfaces and subsequent colonization [83]. The retraction and extension of type IV pili, which propel the cells along the surfaces, is linked to the flagellumindependent type of surface motility. [84]. Moreover, these pili are polarly located hair-like filamentous appendages. The structure of pili can be divided as follows subcomplex: (i) PilBTUCD (the cytoplasmic motor), (ii) PilMNOP (the inner membrane alignment), and (iii) PilQF (OM secretin pore) [85].

As they mediate motility and adhesion, pili are considered crucial elements for initiating infections. Additionally, these elements control twitching motility, which is used for prompt colonization of different surfaces [86], implying that sequential cycles of extension, adhesion, and retraction of T4P fibers generate the force to drive the bacterial cell forward [87]. The pilus movement occurs through two cytoplasmic membrane-associated ATPases, which, respectively, polymerize and depolymerize PilA [86]. Moreover, natural transformation and biofilm formation are probably associated with the binding of pili tips to DNA [88].

\subsection{Immune Evasion (Elastase and Alkaline Protease)}

LasA and LasB elastases, type IV protease (PIV), P. aeruginosa small protease (PASP), Large ExoProtease A (LepA), alkaline protease (AprA), P. aeruginosa aminopeptidase (PAAP), and MucD are extracellular proteases associated with critical invasion in acute infection caused by P. aeruginosa [89].

LasB and LasA elastases are secreted by T2SS regulated by QS systems degrading host elastin [90]. LasB elastase is a metalloprotease and the most abundant protease, the main extracellular virulence factor and is encoded by the lasB gene. Recently, antibiotic resistance in clinical isolates of $P$. aeruginosa has been correlated with LasA expression.

Alkaline protease, which is called aeruginolysin in P. aeruginosa, another metalloendopeptidase produced through T1SS (aprA gene encoded) [91] which interferes with endothelial components (fibronectin and laminin) and degrades cytokines (IFN, TNF, and IL-6) and complement proteins (C1q, C2, and C3), allows phagocytic evasion. It also cleaves free flagellin monomers, reducing the mucociliary clearance of bacteria through epithelial sodium channel activation [92-94], and contributes to the production of pyocyanin (and other virulence factors) [95].

\subsection{Antibiotic Resistance (Pump Efflux and Modifying Enzymes)}

$\beta$-lactamases production has been the most important antimicrobial resistance mechanism, once $\beta$-lactams are the first line therapy, including piperacillin, ceftazidime, cefepime, ceftolozane, carbapenem, and others [96]. The most important $\beta$-lactamases in P. aeruginosa are cephalosporinases, ampC hyper-expression, extended-spectrum $\beta$-lactamases, and carbapenemases. Currently, carbapenemases has been the major challenge, reducing therapeutic options to just a few, including old and toxic drugs (polymyxins and aminoglycosides) [97-102]. 
The efflux pump systems, responsible for expelling antibiotics out of the cell, are among the best described resistance features [103]. It is important to highlight that drug-resistant P. aeruginosa has become an international problem. Efflux pumps have been reported to contribute to the highest level of resistance in synchronization with bacterial biofilms and outer membrane barriers [104-107]. In this mechanism, the crucial cause of antibiotic multidrug resistance is associated with efflux transporters [108].

The high-level resistance in numerous bacterial species is result of enzymatic modifications of aminoglycosides. Among the important resistance genes transferable between Gram-negative bacteria, mainly in P. aeruginosa, are the aminoglycoside-modifying enzyme (AME)-encoding genes [109]. Aminoglycosides are considered the most powerful drugs of choice for the treatment of life-threatening infections caused by P. aeruginosa. However, enzymatic modification is one of the most important mechanisms that lead to resistance against them [110].

AMEs are classified as acetyltransferases (AACs), nucleotidyltransferases (ANTs), and phosphotransferases (APH) [111], which initiate N-acetylation, O-nucleotidylation, and/or O-phosphorylation of the aminoglycosides, respectively, resulting in the inactivation of drugs and therapeutic ineffectiveness [111,112]. Moreover, mobile genetic elements (integrons, plasmids, and transposons) can assist in the prompt spreading of clinically important genes [113]. Further, a group linked the main cause for resistance to aminoglycosides in MDR isolates of P. aeruginosa to the presence of AME genes [114].

\subsection{Cytotoxicity (HCN, Exotoxin A, T3SS, and Pyocyanin)}

Only a few bacterial species such as P. aeruginosa synthesize HCN. Cyanide is a secondary metabolite that can inhibit many cellular processes; it has been reported that $\mathrm{HCN}$ inhibits aerobic respiration [115]. HCN is detectable in the headspace of in vitro P. aeruginosa cultures $[116,117]$ and can be found in samples of sputum of cystic fibrosis patients infected with $P$. aeruginosa [118].

Exotoxin A is classified as the major P. aeruginosa toxigenic virulence factor exocyted through T2SS by most of the isolates [119]. It is divided into three structural domains and one subdomain. The N-terminal domain (I), responsible for attachment to host cells, is composed primarily of antiparallel $\beta$-strands; the middle domain (II) is composed of six $\alpha$-helices with membrane translocating activity; and the C-terminal domain (III) is the toxic moiety [120].

The $P$. aeruginosa T3SS, responsible for injecting toxic effectors into the host cell cytosol (injectisome), is composed of several proteins, including (i) a secretion apparatus (transmembrane transports effectors) and (ii) a translocation apparatus (moves the effectors through human cell membranes) [121]. The secretion apparatus has a helically polymerized protein $(\mathrm{PscF})$ and a cytoplasmic ATPase $(\mathrm{PscN})$, an IM lipoprotein ring (PscJ), and an oligomerized secretin ring at the OM (PscC). Two hydrophobic proteins (PopB and PopD) comprehend the translocation apparatus, interacting with the human cells membrane. They form a pore of translocation, and PcrV (a hydrophilic protein), which are necessary for the perfect assembly and insertion of PopB and PopD into human cell surface [121].

T3SS is not required for infection, however, it enhances the infection severity, enabling $P$. aeruginosa to cause injury of the epithelium, and disseminating into the circulation and counteracting host innate immune responses (through an effector-independent or dependent pathway) [121].

The blue-greenish color of P. aeruginosa colonies in culture can be related to pyocyanin, which is a redox-active secondary metabolite [91]. The disease severity and lung function decline due to this phenazine secreted by T2SS result from its free radical and proinflammatory effects [122]. It can increase intracellular ROS and $\mathrm{H}_{2} \mathrm{O}_{2}$ levels, inducing oxidative stress and damaging several enzymes, components of the cell cycle, and DNA; this leads to cell lysis [122]. As a result, eDNA is released, and this may contribute to biofilm formation and the persistence of infections [123]. Mitochondrial ROS release is also induced, leading to neutrophil apoptosis [124]. In addition, pyocyanin causes epithelial 
disruption by slowing the ciliary beating. It also increases respiratory mucous production, contributing to lung colonization. This phenomenon also increases IL-8 synthesis by alveolar macrophages [122].

\subsection{Iron Scavenging (Proteases and Siderophores)}

Pyochelin is a siderophore based on salicylate with a low iron affinity, whereas pyoverdine (PVD) is a peptide [125]. The process of PVD production consumes energy in P. aeruginosa, which primarily produces pyochelin, and switches to PVD production only when the iron concentration becomes really low [126]. PVD comprises a binding iron conserved dihydroxyquinoline chromophore. It is reported that more than fifty pyoverdines are produced, but they are classified into three types based on the variation in the peptide chain (PVDI, PVDII, and PVDIII) [125]. One of the pyoverdine (PVD) scavenges iron from human proteins accomplished through a membrane network as well as efflux-pumps and transporters in the periplasmic space [127]. Although essential, high concentration of iron produces reactive oxygen species, which leads to cytotoxic effect in the cells [128]. Therefore, this system is shut off by the ferric uptake regulator (called Fur) when sufficient intracellular iron is present [129]. The ECM is important to maintain balance in biofilms, since it stores the iron sequestered within the three EPSs (29948830). PVD acts as a signaling molecule to produce ETA, an endoproteinase (PrpL), and PVD itself.

\section{Pseudomonas aeruginosa Biofilm Treatment}

Owing to increasing antibiotic resistance and the extensive spread of associated infections, treatment failure has become a major global concern; P. aeruginosa has shown great intrinsic resistance to a range of antibiotics, such as beta-lactams, fluoroquinolones, and aminoglycosides, resulting in relevant morbidity and mortality rates [130]. The most common treatment for P. aeruginosa infection is therapy with beta-lactams, whereas carbapenems are the last safe therapeutic alternatives for many MDR infections.

The low antibiotic permeability of the outer membrane (chromosomally encoded AmpC), and drug efflux via multidrug efflux (Mex) systems are the major factors of resistance [131]. Pseudomonas aeruginosa has different mechanisms for resistance to various antibiotics, such as horizontal gene transfer and mutation-driven resistance [130,132]. It has been highlighted that MDR P. aeruginosa acquire mobile genetic elements (transposons, resistance islands, prophages, integrons, and plasmids) through transmission and accommodate them in antibiotic resistance genes [133]. Some of the consequences of this are biofilm formation and the prevalence of inherent and acquired antibiotic resistance of $P$. aeruginosa in recent years. These have led to a situation where there are few effective antibiotics available to stop this bacterium [134]. Additionally, it has been noted that the minimum inhibitory concentrations (MICs) of bacteria inside biofilms may be 10-10,000 times higher than that of planktonic cells [135-137].

\section{Therapeutics for Pseudomonas aeruginosa Infections}

Pseudomonas aeruginosa infections are a great concern as they make the clinical use of regular antimicrobials challenging for therapeutic management. In addition, $P$. aeruginosa is known to present multiple drug tolerance apparatus, which can be divided as follows: (i) intrinsic, (ii) acquired, and (iii) adaptive mechanisms. It is important to point out that biofilm formation is an adaptive mechanism. Survival under exposure to antibiotics and the initiation of chronic infections are crucially associated with this mechanism, which is a virulence factor enhancer [130]. Multifactorial processes are associated with the development and dispersal of biofilms, which require QS systems, c-di-GMP and exopolysaccharides [138]. Hence, reversing strategies are needed to achieve different constituents of the biofilm-residing cells and matrix [139].

Furthermore, it is crucial to ponder the interplay among the host immune system and the bacteria when managing biofilm-related infections [140,141]. Essentially, chronic infections are commonly polymicrobial, which complicate the patient outcomes compared 
to monomicrobial infections. This scenario has significantly influenced the biofilm therapeutic strategies aimed at disrupting the biofilm communities of mono-species $[142,143]$. Inducing biofilm dispersal, inhibiting QS, and targeting iron metabolism using different antimicrobial agents, including antimicrobial peptides, QS inhibitors, biofilm-degrading enzymes, and iron chelators, are some strategies that have been evaluated to overcome these issues. A promising alternative to combat the pathogenicity of $P$. aeruginosa is the use of human probiotic bacteria, such as Lactobacillus casei CRL 431 and Lactobacillus acidophilus CRL 730, with the intention of mitigating P. aeruginosa biofilm strength and virulence by QS inhibition through metabolites [144].

\section{Therapeutic Options for Pseudomonas aeruginosa Infections}

Research on antimicrobials is focused on exploring new approaches and therapies beyond conventional antibiotics, such as bacteriophages, antimicrobial peptides with diverse structures and mechanisms of action, virulence inhibitors, siderophores, compounds of natural origin (e.g., oils), and other adjuvants (e.g., efflux pump inhibitors, monoclonal antibodies), owing to the astounding increase in antimicrobial resistance rates in all types of bacteria $[134,145,146]$.

Researchers have been investigating new methods to inhibit $P$. aeruginosa biofilms. Recently, some studies have indicated that phage therapy is an effective approach for destroying P. aeruginosa biofilms $[147,148]$. Other novel methods aimed at suppressing the biofilms formed by P. aeruginosa, such as small molecule-based inhibitors, phytochemicals, bacteriophage therapy, photodynamic therapy, antimicrobial peptides, monoclonal antibodies, and nanoparticles, are being considered [149].

Medical device-related biofilm infections are a great concern. The development of materials resistant to biofilm colonization is a great strategy to prevent such infections. Some strategies to make materials less susceptible to biofilm attachment involve impregnation of devices with antimicrobial compounds, use of nanoparticle-embedded materials, or modulation of the nanostructure of materials [150].

An example of the impregnation of devices is the silver coating of endotracheal tubes (ETTs), which has demonstrated efficacy against $P$. aeruginosa infection. In an experimental canine model of $P$. aeruginosa VAP, an ETT coated with an antimicrobial silver hydrogel coating underwent notably less $P$. aeruginosa colonization and inflammation than an uncoated ETT [151]. In another large, prospective, single-blind, randomized, controlled study, it was noticed that patients who received a silver-coated ETT exhibited a significant reduction in the incidence of VAP and recurrence compared with those who received an uncoated tube [152], suggesting that antibacterial coating may prevent biofilm developing and reduce VAP incidence.

In addition, a research group found that the strategy of using bacteriophage cocktailcoated tubes had the potential to control the ETT-associated P. aeruginosa biofilms [153].

Newer approaches to inhibit $P$. aeruginosa QS signaling are being sought. To this end, halogenated furanones (HF) of macroalga Delisea pulchra were the first bacterial QS inhibitors identified. Despite not demonstrating activity against $P$. aeruginosa QS, synthetic furanones have been developed. A variety of synthetic HF compounds have been evaluated and demonstrated biofilm biomass reduction, increase the susceptibility of $P$. aeruginosa biofilms to tobramycin in vitro. Moreover, this approach decreased the pathogenicity of P. aeruginosa in vivo in mouse pulmonary infection models [154,155]. The development of novel synthetic furanones through a variety of biochemical screens is currently the focus of attention [156,157].

Diverse natural compounds (and their derivatives) that can inhibit QS have been investigated. For instance, an increase in the antimicrobial susceptibility of $P$. aeruginosa and a decrease in the pathogenicity were observed upon the application of garlic extract, specifically ajoene, the chemical found in garlic, which inhibited QS-mediated virulence factors $[158,159]$. In contrast, a clinical study using garlic in patients with cystic fibrosis and chronic $P$. aeruginosa infection showed a significant difference compared with the 
controls [160]. Patulin (a metabolite produced by Penicillium spp.) decreased P. aeruginosa virulence in vitro, resulting in increased bacterial clearance in a mouse pneumonia model [161]. Several other natural compounds have also been evaluated [162,163] using in vitro systems, including iberin, found in horseradish [162], eugenol, found in clove extract [163], and ellagic acid from Terminalia chebula fruit [15]. However, further studies are necessary to investigate these compounds using preclinical models.

QS inhibition effects have been evaluated using azithromycin and erythromycin [164,165]. For instance, a study using azithromycin showed decreased inflammation in a mouse model of chronic P. aeruginosa pulmonary infection [166]. In addition, individuals with cystic fibrosis and P. aeruginosa infection showed improved clinical outcomes when using azithromycin [167].

Another strategy for QS inhibition is therapy using quorum-quenching enzymes, for instance, acylases and lactonases. These degrade AHLs, or oxireductases, which inactivate AHLs via modification [168]. A reduction in lung injury and mortality from $75 \%$ to $20 \%$ in a rat $P$. aeruginosa model was observed upon nasal administration of the lactonase, SsoPox-1, which attenuated QS signaling, virulence factor production, and biofilm formation in vitro [168]. In nematode infection models and in vitro systems using P. aeruginosa, it was demonstrated that AHL acylases, such as AiiD acylase and PvdQ, and the oxidoreductase Bpi09 also produce favorable results [169-171].

Enzymes with lactonase activity that are expressed by host cells are classified as PONs. These enzymes, mainly PON-2, are capable of hydrolyzing AHL molecules and thereby inhibiting QS and downstream virulence and biofilm formation [172,173]. It has been reported that mice deficient in PON exhibit a marked impairment in their ability to hydrolyze 3-oxo-C12-HSL and clear P. aeruginosa [174]. In patients with cystic fibrosis, lower incidence of PON-2 expression was associated with a higher incidence of $P$. aeruginosa infections [175]. In addition, it was pointed out that $P$. aeruginosa has the ability to directly modulate the host response by attenuating PON-2, which is mediated by the QS molecule 3-oxo-C12-HSL [176,177].

Novel therapies against biofilms, such as the suppression of c-di-GMP signaling, have been proposed owing to the importance of c-di-GMP signaling in biofilm formation and dispersal. This was evaluated through a study, which used a foreign body infection model of $P$. aeruginosa. It was observed that the levels of c-di-GMP could be reduced by inducing a phosphodiesterase. Moreover, the attenuation of bacterial c-di-GMP signaling enabled greater clearance of the infection [178]. However, a study using doxorubicin (previously identified as a potent c-di-GMP inhibitor in a large screen) paradoxically showed an increase in biofilm size [179]. Despite these advances, further studies are necessary to ascertain whether suppression of c-di-GMP signaling is a potential therapy.

Organisms from all classes of life produce peptides with antimicrobial properties, and several synthetic antimicrobial peptides have been developed [180]. Some of these peptides decrease the attachment of bacterial cells, preventing bacterial biofilm formation [181]. Optimistic findings were obtained when analyzing these peptides in in vitro systems. However, further studies are necessary before these discoveries can be translated into clinical studies [182-184].

\section{Conclusions}

The pathogenicity mechanisms of $P$. aeruginosa biofilms, including their characteristics and QS properties, are extremely complex. Although the structure of a biofilm seems to be simple, the genes and mechanisms involved in biofilm formation are diverse and hard to comprehend. Furthermore, most of the studies to identify them have been conducted in vitro, which is not the real situation in human infections. The use of transcriptomics and metabolomics to analyze clinical sample could be an approach to address this. However, it would be difficult to separate the results pertaining to P. aeruginosa from those of other bacteria, since most of these infections are polymicrobial and involve local microbiota. 
It is important to elucidate the interaction of $P$. aeruginosa with the host for the further development of new therapies.

Author Contributions: Conceptualization: F.F.T., L.R.D., P.H.S., and V.S.T.R.; writing—original draft preparation: F.F.T., L.R.D., P.H.S., and V.S.T.R.; writing-review and editing: F.F.T., L.R.D., P.H.S., and V.S.T.R. All authors have read and agreed to the published version of the manuscript.

Funding: This research received no external funding.

Institutional Review Board Statement: Not applicable.

Informed Consent Statement: Not applicable.

Data Availability Statement: Not applicable.

Conflicts of Interest: F. F. Tuon is a CNPq researcher. The other authors declare no conflict of interest.

\section{References}

1. Stover, C.K.; Pham, X.Q.; Erwin, A.L.; Mizoguchi, S.D.; Warrener, P.; Hickey, M.J.; Brinkman, F.S.; Hufnagle, W.O.; Kowalik, D.J.; Lagrou, M.; et al. Complete genome sequence of Pseudomonas aeruginosa PAO1, an opportunistic pathogen. Nature 2000, 406, 959-964. [CrossRef] [PubMed]

2. $\quad$ Remold, S.K.; Brown, C.K.; Farris, J.E.; Hundley, T.C.; Perpich, J.A.; Purdy, M.E. Differential habitat use and niche partitioning by Pseudomonas species in human homes. Microb. Ecol. 2011, 62, 505-517. [CrossRef] [PubMed]

3. Hendrie, C.A. Naloxone-sensitive hyperalgesia follows analgesia induced by morphine and environmental stimulation. Pharmacol. Biochem. Behav. 1989, 32, 961-966. [CrossRef]

4. Shariati, A.; Azimi, T.; Ardebili, A.; Chirani, A.S.; Bahramian, A.; Pormohammad, A.; Sadredinamin, M.; Erfanimanesh, S.; Bostanghadiri, N.; Shams, S.; et al. Insertional inactivation of oprD in carbapenem-resistant Pseudomonas aeruginosa strains isolated from burn patients in Tehran, Iran. N. Microbes N. Infect. 2018, 21, 75-80. [CrossRef] [PubMed]

5. Ito, C.A.S.; Bail, L.; Arend, L.; Nogueira, K.D.S.; Tuon, F.F. The activity of ceftazidime/avibactam against carbapenem-resistant Pseudomonas aeruginosa. Infect. Dis. 2021, 53, 386-389. [CrossRef]

6. Kalluf, K.O.; Arend, L.N.; Wuicik, T.E.; Pilonetto, M.; Tuon, F.F. Molecular epidemiology of SPM-1-producing Pseudomonas aeruginosa by rep-PCR in hospitals in Parana, Brazil. Infect. Genet. Evol. 2017, 49, 130-133. [CrossRef]

7. Ramos, G.P.; Rocha, J.L.; Tuon, F.F. Seasonal humidity may influence Pseudomonas aeruginosa hospital-acquired infection rates. Int. J. Infect. Dis. 2013, 17, e757-e761. [CrossRef]

8. Tuon, F.F.; Gortz, L.W.; Rocha, J.L. Risk factors for pan-resistant Pseudomonas aeruginosa bacteremia and the adequacy of antibiotic therapy. Braz. J. Infect. Dis. 2012, 16, 351-356. [CrossRef]

9. Turkina, M.V.; Vikstrom, E. Bacteria-Host Crosstalk: Sensing of the Quorum in the Context of Pseudomonas aeruginosa Infections. J. Innate Immun. 2019, 11, 263-279. [CrossRef]

10. Nathwani, D.; Raman, G.; Sulham, K.; Gavaghan, M.; Menon, V. Clinical and economic consequences of hospital-acquired resistant and multidrug-resistant Pseudomonas aeruginosa infections: A systematic review and meta-analysis. Antimicrob Resist. Infect. Control. 2014, 3, 32. [CrossRef]

11. Zowawi, H.M.; Harris, P.N.; Roberts, M.J.; Tambyah, P.A.; Schembri, M.A.; Pezzani, M.D.; Williamson, D.A.; Paterson, D.L. The emerging threat of multidrug-resistant Gram-negative bacteria in urology. Nat. Rev. Urol. 2015, 12, 570-584. [CrossRef]

12. Tuon, F.F.; Cieslinski, J.; Rodrigues, S.D.S.; Serra, F.B.; Paula, M.D. Evaluation of in vitro activity of ceftolozane-tazobactam against recent clinical bacterial isolates from Brazil-The EM200 study. Braz. J. Infect. Dis. 2020, 24, 96-103. [CrossRef]

13. Ito, C.A.S.; Bail, L.; Arend, L.; Silva, K.O.; Michelotto, S.S.; Nogueira, K.D.S.; Tuon, F.F. Evaluation of MicroScan WalkAway for Determination of Ceftazidime-Avibactam and Ceftolozane-Tazobactam Susceptibility in Carbapenem-Resistant Gram-Negative Bacilli. J. Clin. Microbiol. 2021, 59, e0153621. [CrossRef] [PubMed]

14. Bail, L.; Ito, C.A.S.; Arend, L.; Nogueira, K.D.S.; Tuon, F.F. Activity of imipenem-relebactam and ceftolozane-tazobactam against carbapenem-resistant Pseudomonas aeruginosa and KPC-producing Enterobacterales. Diagn. Microbiol. Infect. Dis. 2021, 102, 115568. [CrossRef] [PubMed]

15. Sarabhai, S.; Sharma, P.; Capalash, N. Ellagic acid derivatives from Terminalia chebula Retz. downregulate the expression of quorum sensing genes to attenuate Pseudomonas aeruginosa PAO1 virulence. PLoS ONE 2013, 8, e53441. [CrossRef] [PubMed]

16. Kang, C.I.; Kim, S.H.; Kim, H.B.; Park, S.W.; Choe, Y.J.; Oh, M.D.; Kim, E.C.; Choe, K.W. Pseudomonas aeruginosa bacteremia: Risk factors for mortality and influence of delayed receipt of effective antimicrobial therapy on clinical outcome. Clin. Infect. Dis. 2003, 37, 745-751. [CrossRef]

17. Reynolds, D.; Kollef, M. The Epidemiology and Pathogenesis and Treatment of Pseudomonas aeruginosa Infections: An Update. Drugs 2021, 81, 2117-2131. [CrossRef] [PubMed]

18. Ghafoor, A.; Hay, I.D.; Rehm, B.H. Role of exopolysaccharides in Pseudomonas aeruginosa biofilm formation and architecture. Appl. Environ. Microbiol. 2011, 77, 5238-5246. [CrossRef] 
19. Costerton, J.W.; Stewart, P.S.; Greenberg, E.P. Bacterial biofilms: A common cause of persistent infections. Science 1999, 284, 1318-1322. [CrossRef]

20. Stewart, P.S.; Costerton, J.W. Antibiotic resistance of bacteria in biofilms. Lancet 2001, 358, 135-138. [CrossRef]

21. Filloux, A.; Vallet, I. Biofilm: Set-up and organization of a bacterial community. Med. Sci 2003, 19, 77-83. [CrossRef]

22. Vu, B.; Chen, M.; Crawford, R.J.; Ivanova, E.P. Bacterial extracellular polysaccharides involved in biofilm formation. Molecules 2009, 14, 2535-2554. [CrossRef] [PubMed]

23. Davey, M.E.; O’Toole, G.A. Microbial biofilms: From ecology to molecular genetics. Microbiol. Mol. Biol. Rev. 2000, 64, 847-867. [CrossRef] [PubMed]

24. Al-Wrafy, F.; Brzozowska, E.; Gorska, S.; Gamian, A. Pathogenic factors of Pseudomonas aeruginosa-The role of biofilm in pathogenicity and as a target for phage therapy. Postepy Hig. Med. Dosw. 2017, 71, 78-91. [CrossRef]

25. Wessel, A.K.; Arshad, T.A.; Fitzpatrick, M.; Connell, J.L.; Bonnecaze, R.T.; Shear, J.B.; Whiteley, M. Oxygen limitation within a bacterial aggregate. mBio 2014, 5, e00992. [CrossRef]

26. Schreiber, F.; Littmann, S.; Lavik, G.; Escrig, S.; Meibom, A.; Kuypers, M.M.; Ackermann, M. Phenotypic heterogeneity driven by nutrient limitation promotes growth in fluctuating environments. Nat. Microbiol. 2016, 1, 16055. [CrossRef]

27. Vroom, J.M.; De Grauw, K.J.; Gerritsen, H.C.; Bradshaw, D.J.; Marsh, P.D.; Watson, G.K.; Birmingham, J.J.; Allison, C. Depth penetration and detection of $\mathrm{pH}$ gradients in biofilms by two-photon excitation microscopy. Appl. Environ. Microbiol. 1999, 65, 3502-3511. [CrossRef]

28. Stewart, P.S.; Franklin, M.J. Physiological heterogeneity in biofilms. Nat. Rev. Microbiol. 2008, 6, 199-210. [CrossRef]

29. Ma, L.; Conover, M.; Lu, H.; Parsek, M.R.; Bayles, K.; Wozniak, D.J. Assembly and development of the Pseudomonas aeruginosa biofilm matrix. PLoS Pathog. 2009, 5, e1000354. [CrossRef]

30. Spoering, A.L.; Lewis, K. Biofilms and planktonic cells of Pseudomonas aeruginosa have similar resistance to killing by antimicrobials. J. Bacteriol. 2001, 183, 6746-6751. [CrossRef]

31. Sauer, K.; Camper, A.K. Characterization of phenotypic changes in Pseudomonas putida in response to surface-associated growth J. Bacteriol. 2001, 183, 6579-6589. [CrossRef]

32. Davies, D.G.; Geesey, G.G. Regulation of the alginate biosynthesis gene algC in Pseudomonas aeruginosa during biofilm development in continuous culture. Appl. Environ. Microbiol. 1995, 61, 860-867. [CrossRef] [PubMed]

33. Whiteley, M.; Bangera, M.G.; Bumgarner, R.E.; Parsek, M.R.; Teitzel, G.M.; Lory, S.; Greenberg, E.P. Gene expression in Pseudomonas aeruginosa biofilms. Nature 2001, 413, 860-864. [CrossRef] [PubMed]

34. Sauer, K.; Camper, A.K.; Ehrlich, G.D.; Costerton, J.W.; Davies, D.G. Pseudomonas aeruginosa displays multiple phenotypes during development as a biofilm. J. Bacteriol. 2002, 184, 1140-1154. [CrossRef] [PubMed]

35. Guo, Q.; Kong, W.; Jin, S.; Chen, L.; Xu, Y.; Duan, K. PqsR-dependent and PqsR-independent regulation of motility and biofilm formation by PQS in Pseudomonas aeruginosa PAO1. J. Basic Microbiol. 2014, 54, 633-643. [CrossRef]

36. Lister, P.D.; Wolter, D.J.; Hanson, N.D. Antibacterial-resistant Pseudomonas aeruginosa: Clinical impact and complex regulation of chromosomally encoded resistance mechanisms. Clin. Microbiol. Rev. 2009, 22, 582-610. [CrossRef]

37. Ciszek-Lenda, M.; Strus, M.; Walczewska, M.; Majka, G.; Machul-Zwirbla, A.; Mikolajczyk, D.; Gorska, S.; Gamian, A.; Chain, B.; Marcinkiewicz, J. Pseudomonas aeruginosa biofilm is a potent inducer of phagocyte hyperinflammation. Inflamm. Res. 2019, 68, 397-413. [CrossRef]

38. Mann, E.E.; Wozniak, D.J. Pseudomonas biofilm matrix composition and niche biology. FEMS Microbiol. Rev. 2012, 36, 893-916. [CrossRef]

39. Orgad, O.; Oren, Y.; Walker, S.L.; Herzberg, M. The role of alginate in Pseudomonas aeruginosa EPS adherence, viscoelastic properties and cell attachment. Biofouling 2011, 27, 787-798. [CrossRef]

40. Ryder, C.; Byrd, M.; Wozniak, D.J. Role of polysaccharides in Pseudomonas aeruginosa biofilm development. Curr. Opin. Microbiol. 2007, 10, 644-648. [CrossRef]

41. Leid, J.G.; Willson, C.J.; Shirtliff, M.E.; Hassett, D.J.; Parsek, M.R.; Jeffers, A.K. The exopolysaccharide alginate protects Pseudomonas aeruginosa biofilm bacteria from IFN-gamma-mediated macrophage killing. J. Immunol. 2005, 175, 7512-7518. [CrossRef] [PubMed]

42. Rybtke, M.; Jensen, P.O.; Nielsen, C.H.; Tolker-Nielsen, T. The Extracellular Polysaccharide Matrix of Pseudomonas aeruginosa Biofilms Is a Determinant of Polymorphonuclear Leukocyte Responses. Infect. Immun. 2020, 89, e00631-20. [CrossRef]

43. Goltermann, L.; Tolker-Nielsen, T. Importance of the Exopolysaccharide Matrix in Antimicrobial Tolerance of Pseudomonas aeruginosa Aggregates. Antimicrob. Agents Chemother. 2017, 61, e02696-16. [CrossRef] [PubMed]

44. Malesevic, M.; Stanisavljevic, N.; Novovic, K.; Polovic, N.; Vasiljevic, Z.; Kojic, M.; Jovcic, B. Burkholderia cepacia YtnP and Y2-aiiA lactonases inhibit virulence of Pseudomonas aeruginosa via quorum quenching activity. Microb. Pathog. 2020, $149,104561$. [CrossRef]

45. Halldorsson, S.; Gudjonsson, T.; Gottfredsson, M.; Singh, P.K.; Gudmundsson, G.H.; Baldursson, O. Azithromycin maintains airway epithelial integrity during Pseudomonas aeruginosa infection. Am. J. Respir. Cell Mol. Biol. 2010, 42, 62-68. [CrossRef] [PubMed]

46. Zulianello, L.; Canard, C.; Kohler, T.; Caille, D.; Lacroix, J.S.; Meda, P. Rhamnolipids are virulence factors that promote early infiltration of primary human airway epithelia by Pseudomonas aeruginosa. Infect. Immun. 2006, 74, 3134-3147. [CrossRef] [PubMed] 
47. Kohler, T.; Guanella, R.; Carlet, J.; van Delden, C. Quorum sensing-dependent virulence during Pseudomonas aeruginosa colonisation and pneumonia in mechanically ventilated patients. Thorax 2010, 65, 703-710. [CrossRef]

48. Davey, M.E.; Caiazza, N.C.; O'Toole, G.A. Rhamnolipid surfactant production affects biofilm architecture in Pseudomonas aeruginosa PAO1. J. Bacteriol. 2003, 185, 1027-1036. [CrossRef]

49. Murray, T.S.; Kazmierczak, B.I. Pseudomonas aeruginosa exhibits sliding motility in the absence of type IV pili and flagella. J. Bacteriol. 2008, 190, 2700-2708. [CrossRef]

50. Tremblay, J.; Richardson, A.P.; Lepine, F.; Deziel, E. Self-produced extracellular stimuli modulate the Pseudomonas aeruginosa swarming motility behaviour. Environ. Microbiol. 2007, 9, 2622-2630. [CrossRef]

51. Wang, S.; Yu, S.; Zhang, Z.; Wei, Q.; Yan, L.; Ai, G.; Liu, H.; Ma, L.Z. Coordination of swarming motility, biosurfactant synthesis, and biofilm matrix exopolysaccharide production in Pseudomonas aeruginosa. Appl. Environ. Microbiol. 2014, 80, 6724-6732. [CrossRef] [PubMed]

52. Jensen, P.O.; Bjarnsholt, T.; Phipps, R.; Rasmussen, T.B.; Calum, H.; Christoffersen, L.; Moser, C.; Williams, P.; Pressler, T.; Givskov, M.; et al. Rapid necrotic killing of polymorphonuclear leukocytes is caused by quorum-sensing-controlled production of rhamnolipid by Pseudomonas aeruginosa. Microbiology 2007, 153, 1329-1338. [CrossRef] [PubMed]

53. Dossel, J.; Meyer-Hoffert, U.; Schroder, J.M.; Gerstel, U. Pseudomonas aeruginosa-derived rhamnolipids subvert the host innate immune response through manipulation of the human beta-defensin-2 expression. Cell Microbiol. 2012, 14, 1364-1375. [CrossRef] [PubMed]

54. Heydorn, A.; Ersboll, B.; Kato, J.; Hentzer, M.; Parsek, M.R.; Tolker-Nielsen, T.; Givskov, M.; Molin, S. Statistical analysis of Pseudomonas aeruginosa biofilm development: Impact of mutations in genes involved in twitching motility, cell-to-cell signaling, and stationary-phase sigma factor expression. Appl. Environ. Microbiol. 2002, 68, 2008-2017. [CrossRef] [PubMed]

55. Lee, J.; Zhang, L. The hierarchy quorum sensing network in Pseudomonas aeruginosa. Protein Cell 2015, 6, 26-41. [CrossRef]

56. Kumar, R.; Chhibber, S.; Harjai, K. Quorum sensing is necessary for the virulence of Pseudomonas aeruginosa during urinary tract infection. Kidney Int. 2009, 76, 286-292. [CrossRef]

57. Rutherford, S.T.; Bassler, B.L. Bacterial quorum sensing: Its role in virulence and possibilities for its control. Cold Spring Harb. Perspect. Med. 2012, 2, a012427. [CrossRef]

58. Gambello, M.J.; Iglewski, B.H. Cloning and characterization of the Pseudomonas aeruginosa lasR gene, a transcriptional activator of elastase expression. J. Bacteriol. 1991, 173, 3000-3009. [CrossRef]

59. Gambello, M.J.; Kaye, S.; Iglewski, B.H. LasR of Pseudomonas aeruginosa is a transcriptional activator of the alkaline protease gene (apr) and an enhancer of exotoxin A expression. Infect. Immun. 1993, 61, 1180-1184. [CrossRef]

60. Pearson, J.P.; Gray, K.M.; Passador, L.; Tucker, K.D.; Eberhard, A.; Iglewski, B.H.; Greenberg, E.P. Structure of the autoinducer required for expression of Pseudomonas aeruginosa virulence genes. Proc. Natl. Acad. Sci. USA 1994, 91, 197-201. [CrossRef]

61. Pearson, J.P.; Passador, L.; Iglewski, B.H.; Greenberg, E.P. A second N-acylhomoserine lactone signal produced by Pseudomonas aeruginosa. Proc. Natl. Acad. Sci. USA 1995, 92, 1490-1494. [CrossRef] [PubMed]

62. Ochsner, U.A.; Reiser, J. Autoinducer-mediated regulation of rhamnolipid biosurfactant synthesis in Pseudomonas aeruginosa. Proc. Natl. Acad. Sci. USA 1995, 92, 6424-6428. [CrossRef] [PubMed]

63. Pesci, E.C.; Milbank, J.B.; Pearson, J.P.; McKnight, S.; Kende, A.S.; Greenberg, E.P.; Iglewski, B.H. Quinolone signaling in the cell-to-cell communication system of Pseudomonas aeruginosa. Proc. Natl. Acad. Sci. USA 1999, 96, 11229-11234. [CrossRef] [PubMed]

64. Lee, J.; Wu, J.; Deng, Y.; Wang, J.; Wang, C.; Wang, J.; Chang, C.; Dong, Y.; Williams, P.; Zhang, L.H. A cell-cell communication signal integrates quorum sensing and stress response. Nat. Chem. Biol. 2013, 9, 339-343. [CrossRef] [PubMed]

65. Kiratisin, P.; Tucker, K.D.; Passador, L. LasR, a transcriptional activator of Pseudomonas aeruginosa virulence genes, functions as a multimer. J. Bacteriol. 2002, 184, 4912-4919. [CrossRef]

66. Latifi, A.; Foglino, M.; Tanaka, K.; Williams, P.; Lazdunski, A. A hierarchical quorum-sensing cascade in Pseudomonas aeruginosa links the transcriptional activators LasR and RhIR (VsmR) to expression of the stationary-phase sigma factor RpoS. Mol. Microbiol. 1996, 21, 1137-1146. [CrossRef]

67. Pesci, E.C.; Pearson, J.P.; Seed, P.C.; Iglewski, B.H. Regulation of las and rhl quorum sensing in Pseudomonas aeruginosa. J. Bacteriol. 1997, 179, 3127-3132. [CrossRef]

68. Deziel, E.; Lepine, F.; Milot, S.; He, J.; Mindrinos, M.N.; Tompkins, R.G.; Rahme, L.G. Analysis of Pseudomonas aeruginosa 4-hydroxy-2-alkylquinolines (HAQs) reveals a role for 4-hydroxy-2-heptylquinoline in cell-to-cell communication. Proc. Natl. Acad. Sci. USA 2004, 101, 1339-1344. [CrossRef]

69. McKnight, S.L.; Iglewski, B.H.; Pesci, E.C. The Pseudomonas quinolone signal regulates rhl quorum sensing in Pseudomonas aeruginosa. J. Bacteriol. 2000, 182, 2702-2708. [CrossRef]

70. Wu, L.; Estrada, O.; Zaborina, O.; Bains, M.; Shen, L.; Kohler, J.E.; Patel, N.; Musch, M.W.; Chang, E.B.; Fu, Y.X.; et al. Recognition of host immune activation by Pseudomonas aeruginosa. Science 2005, 309, 774-777. [CrossRef]

71. Zaborina, O.; Lepine, F.; Xiao, G.; Valuckaite, V.; Chen, Y.; Li, T.; Ciancio, M.; Zaborin, A.; Petrof, E.O.; Turner, J.R.; et al. Dynorphin activates quorum sensing quinolone signaling in Pseudomonas aeruginosa. PLoS Pathog. 2007, 3, e35. [CrossRef]

72. Blier, A.S.; Veron, W.; Bazire, A.; Gerault, E.; Taupin, L.; Vieillard, J.; Rehel, K.; Dufour, A.; Le Derf, F.; Orange, N.; et al. C-type natriuretic peptide modulates quorum sensing molecule and toxin production in Pseudomonas aeruginosa. Microbiology 2011, 157, 1929-1944. [CrossRef] [PubMed] 
73. Heydorn, A.; Ersboll, B.K.; Hentzer, M.; Parsek, M.R.; Givskov, M.; Molin, S. Experimental reproducibility in flow-chamber biofilms. Microbiology 2000, 146 Pt 10, 2409-2415. [CrossRef] [PubMed]

74. Schuster, M.; Hawkins, A.C.; Harwood, C.S.; Greenberg, E.P. The Pseudomonas aeruginosa RpoS regulon and its relationship to quorum sensing. Mol. Microbiol. 2004, 51, 973-985. [CrossRef]

75. Bouillet, S.; Ba, M.; Houot, L.; Iobbi-Nivol, C.; Bordi, C. Connected partner-switches control the life style of Pseudomonas aeruginosa through RpoS regulation. Sci. Rep. 2019, 9, 6496. [CrossRef]

76. Cooke, A.C.; Florez, C.; Dunshee, E.B.; Lieber, A.D.; Terry, M.L.; Light, C.J.; Schertzer, J.W. Pseudomonas Quinolone SignalInduced Outer Membrane Vesicles Enhance Biofilm Dispersion in Pseudomonas aeruginosa. mSphere 2020, 5, e01109-20. [CrossRef]

77. Schuster, M.; Greenberg, E.P. A network of networks: Quorum-sensing gene regulation in Pseudomonas aeruginosa. Int. J. Med. Microbiol. 2006, 296, 73-81. [CrossRef]

78. Tam, V.H.; Chang, K.T.; Abdelraouf, K.; Brioso, C.G.; Ameka, M.; McCaskey, L.A.; Weston, J.S.; Caeiro, J.P.; Garey, K.W. Prevalence, resistance mechanisms, and susceptibility of multidrug-resistant bloodstream isolates of Pseudomonas aeruginosa. Antimicrob. Agents Chemother. 2010, 54, 1160-1164. [CrossRef]

79. Mues, N.; Chu, H.W. Out-Smarting the Host: Bacteria Maneuvering the Immune Response to Favor Their Survival. Front. Immunol. 2020, 11, 819. [CrossRef]

80. O'Toole, G.A.; Kolter, R. Flagellar and twitching motility are necessary for Pseudomonas aeruginosa biofilm development. Mol. Microbiol. 1998, 30, 295-304. [CrossRef]

81. Sampedro, I.; Parales, R.E.; Krell, T.; Hill, J.E. Pseudomonas chemotaxis. FEMS Microbiol. Rev. 2015, 39, 17-46. [CrossRef] [PubMed]

82. Guttenplan, S.B.; Kearns, D.B. Regulation of flagellar motility during biofilm formation. FEMS Microbiol. Rev. 2013, 37, 849-871. [CrossRef] [PubMed]

83. Hahn, H.P. The type-4 pilus is the major virulence-associated adhesin of Pseudomonas aeruginosa-A review. Gene 1997, 192, 99-108. [CrossRef]

84. Merz, A.J.; So, M.; Sheetz, M.P. Pilus retraction powers bacterial twitching motility. Nature 2000, 407, 98-102. [CrossRef] [PubMed]

85. Jacobsen, T.; Bardiaux, B.; Francetic, O.; Izadi-Pruneyre, N.; Nilges, M. Structure and function of minor pilins of type IV pili. Med. Microbiol. Immunol. 2020, 209, 301-308. [CrossRef] [PubMed]

86. Burrows, L.L. Pseudomonas aeruginosa twitching motility: Type IV pili in action. Annu. Rev. Microbiol. 2012, 66, 493-520. [CrossRef] [PubMed]

87. Tala, L.; Fineberg, A.; Kukura, P.; Persat, A. Pseudomonas aeruginosa orchestrates twitching motility by sequential control of type IV pili movements. Nat. Microbiol. 2019, 4, 774-780. [CrossRef] [PubMed]

88. van Schaik, E.J.; Giltner, C.L.; Audette, G.F.; Keizer, D.W.; Bautista, D.L.; Slupsky, C.M.; Sykes, B.D.; Irvin, R.T. DNA binding: A novel function of Pseudomonas aeruginosa type IV pili. J. Bacteriol. 2005, 187, 1455-1464. [CrossRef]

89. Kida, Y.; Higashimoto, Y.; Inoue, H.; Shimizu, T.; Kuwano, K. A novel secreted protease from Pseudomonas aeruginosa activates NF-kappaB through protease-activated receptors. Cell Microbiol. 2008, 10, 1491-1504. [CrossRef]

90. Li, X.H.; Lee, J.H. Quorum sensing-dependent post-secretional activation of extracellular proteases in Pseudomonas aeruginosa. J. Biol. Chem. 2019, 294, 19635-19644. [CrossRef]

91. Gellatly, S.L.; Hancock, R.E. Pseudomonas aeruginosa: New insights into pathogenesis and host defenses. Pathog. Dis. 2013, 67, 159-173. [CrossRef] [PubMed]

92. Laarman, A.J.; Bardoel, B.W.; Ruyken, M.; Fernie, J.; Milder, F.J.; van Strijp, J.A.; Rooijakkers, S.H. Pseudomonas aeruginosa alkaline protease blocks complement activation via the classical and lectin pathways. J. Immunol. 2012, 188, 386-393. [CrossRef] [PubMed]

93. Butterworth, M.B.; Zhang, L.; Heidrich, E.M.; Myerburg, M.M.; Thibodeau, P.H. Activation of the epithelial sodium channel $(\mathrm{ENaC})$ by the alkaline protease from Pseudomonas aeruginosa. J. Biol. Chem. 2012, 287, 32556-32565. [CrossRef] [PubMed]

94. Bardoel, B.W.; van der Ent, S.; Pel, M.J.; Tommassen, J.; Pieterse, C.M.; van Kessel, K.P.; van Strijp, J.A. Pseudomonas evades immune recognition of flagellin in both mammals and plants. PLoS Pathog. 2011, 7, e1002206. [CrossRef] [PubMed]

95. Iiyama, K.; Takahashi, E.; Lee, J.M.; Mon, H.; Morishita, M.; Kusakabe, T.; Yasunaga-Aoki, C. Alkaline protease contributes to pyocyanin production in Pseudomonas aeruginosa. FEMS Microbiol. Lett. 2017, 364, 1-7. [CrossRef] [PubMed]

96. Noval, M.; Banoub, M.; Claeys, K.C.; Heil, E. The Battle Is on: New Beta-Lactams for the Treatment of Multidrug-Resistant Gram-Negative Organisms. Curr. Infect. Dis. Rep. 2020, 22, 1. [CrossRef] [PubMed]

97. Gasparetto, J.; Pitta, R.; Cordova, K.; Kaczam, K.G.; Takara, C.M.A.; Zanini, G.L.; Abujamra, M.; Cieslinski, J.; de Moraes, T.P.; Tuon, F.F. Acute Kidney Injury in Patients Using Amikacin in Intensive Care Unit-A Paired Case-Control Study with Meropenem. Am. J. Ther. 2020, 27, e403-e405. [CrossRef]

98. Peixoto, B.C.; Contrera, G.G.; Cieslinski, J.; Gasparetto, J.; Tuon, F.F. Acute kidney injury in patients using low dose (3 mg/kg/day) of gentamicin under therapeutic dose monitoring. J. Infect. 2018, 76, 496-498. [CrossRef]

99. Pitta, R.D.; Gasparetto, J.; De Moraes, T.P.; Telles, J.P.; Tuon, F.F. Antimicrobial therapy with aminoglycoside or meropenem in the intensive care unit for hospital associated infections and risk factors for acute kidney injury. Eur. J. Clin. Microbiol. Infect. Dis. 2020, 39, 723-728. [CrossRef] 
100. Tuon, F.F.; Aragao, B.Z.; Santos, T.A.; Gasparetto, J.; Cordova, K.; Abujamra, M. Acute kidney injury in patients using amikacin in an era of carbapenem-resistant bacteria. Infect. Dis. 2016, 48, 3. [CrossRef]

101. Tuon, F.F.; Rigatto, M.H.; Lopes, C.K.; Kamei, L.K.; Rocha, J.L.; Zavascki, A.P. Risk factors for acute kidney injury in patients treated with polymyxin B or colistin methanesulfonate sodium. Int. J. Antimicrob. Agents 2014, 43, 349-352. [CrossRef] [PubMed]

102. Tuon, F.F.; Rocha, J.L.; Gasparetto, J. Polymyxin B and colistin-the economic burden of nephrotoxicity against multidrug resistant bacteria. J. Med. Econ. 2019, 22, 158-162. [CrossRef] [PubMed]

103. Saito, K.; Yoneyama, H.; Nakae, T. nalB-type mutations causing the overexpression of the MexAB-OprM efflux pump are located in the mexR gene of the Pseudomonas aeruginosa chromosome. FEMS Microbiol. Lett. 1999, 179, 67-72. [CrossRef] [PubMed]

104. Daigle, D.M.; Cao, L.; Fraud, S.; Wilke, M.S.; Pacey, A.; Klinoski, R.; Strynadka, N.C.; Dean, C.R.; Poole, K. Protein modulator of multidrug efflux gene expression in Pseudomonas aeruginosa. J. Bacteriol. 2007, 189, 5441-5451. [CrossRef]

105. Dwivedi, G.R.; Tyagi, R.; Sanchita; Tripathi, S.; Pati, S.; Srivastava, S.K.; Darokar, M.P.; Sharma, A. Antibiotics potentiating potential of catharanthine against superbug Pseudomonas aeruginosa. J. Biomol. Struct. Dyn. 2018, 36, 4270-4284. [CrossRef]

106. Li, X.Z.; Nikaido, H.; Poole, K. Role of mexA-mexB-oprM in antibiotic efflux in Pseudomonas aeruginosa. Antimicrob. Agents Chemother. 1995, 39, 1948-1953. [CrossRef]

107. Ozen, A.I.; Ussery, D.W. Defining the Pseudomonas genus: Where do we draw the line with Azotobacter? Microb. Ecol. 2012, 63, 239-248. [CrossRef] [PubMed]

108. Li, X.Z.; Plesiat, P.; Nikaido, H. The challenge of efflux-mediated antibiotic resistance in Gram-negative bacteria. Clin. Microbiol. Rev. 2015, 28, 337-418. [CrossRef]

109. Belaynehe, K.M.; Shin, S.W.; Hong-Tae, P.; Yoo, H.S. Occurrence of aminoglycoside-modifying enzymes among isolates of Escherichia coli exhibiting high levels of aminoglycoside resistance isolated from Korean cattle farms. FEMS Microbiol. Lett. 2017, 364, 1-9. [CrossRef]

110. Odumosu, B.T.; Adeniyi, B.A.; Chandra, R. Occurrence of aminoglycoside-modifying enzymes genes (aac $\left(6^{\prime}\right)-\mathrm{I}$ and ant $\left.\left(2^{\prime \prime}\right)-\mathrm{I}\right)$ in clinical isolates of Pseudomonas aeruginosa from Southwest Nigeria. Afr. Health Sci. 2015, 15, 1277-1281. [CrossRef]

111. Poole, K. Aminoglycoside resistance in Pseudomonas aeruginosa. Antimicrob. Agents Chemother. 2005, 49, 479-487. [CrossRef] [PubMed]

112. Ghotaslou, R.; Yeganeh Sefidan, F.; Akhi, M.T.; Asgharzadeh, M.; Mohammadzadeh Asl, Y. Dissemination of Genes Encoding Aminoglycoside-Modifying Enzymes and armA Among Enterobacteriaceae Isolates in Northwest Iran. Microb. Drug Resist. 2017, 23, 826-832. [CrossRef] [PubMed]

113. Wright, G.D. Aminoglycoside-modifying enzymes. Curr. Opin. Microbiol. 1999, 2, 499-503. [CrossRef]

114. Thirumalmuthu, K.; Devarajan, B.; Prajna, L.; Mohankumar, V. Mechanisms of Fluoroquinolone and Aminoglycoside Resistance in Keratitis-Associated Pseudomonas aeruginosa. Microb. Drug Resist. 2019, 25, 813-823. [CrossRef] [PubMed]

115. Williams, H.D.; Zlosnik, J.E.; Ryall, B. Oxygen, cyanide and energy generation in the cystic fibrosis pathogen Pseudomonas aeruginosa. Adv. Microb. Physiol. 2007, 52, 1-71. [CrossRef]

116. Carroll, W.; Lenney, W.; Wang, T.; Spanel, P.; Alcock, A.; Smith, D. Detection of volatile compounds emitted by Pseudomonas aeruginosa using selected ion flow tube mass spectrometry. Pediatr. Pulmonol. 2005, 39, 452-456. [CrossRef]

117. Gilchrist, F.J.; Alcock, A.; Belcher, J.; Brady, M.; Jones, A.; Smith, D.; Spanel, P.; Webb, K.; Lenney, W. Variation in hydrogen cyanide production between different strains of Pseudomonas aeruginosa. Eur. Respir. J. 2011, 38, 409-414. [CrossRef]

118. Ryall, B.; Davies, J.C.; Wilson, R.; Shoemark, A.; Williams, H.D. Pseudomonas aeruginosa, cyanide accumulation and lung function in CF and non-CF bronchiectasis patients. Eur. Respir. 2008, 32, 740-747. [CrossRef]

119. Javanmardi, F.; Emami, A.; Pirbonyeh, N.; Keshavarzi, A.; Rajaee, M. A systematic review and meta-analysis on Exo-toxins prevalence in hospital acquired Pseudomonas aeruginosa isolates. Infect. Genet. Evol. 2019, 75, 104037. [CrossRef]

120. Michalska, M.; Wolf, P. Pseudomonas Exotoxin A: Optimized by evolution for effective killing. Front. Microbiol. $2015,6,963$. [CrossRef]

121. Anantharajah, A.; Mingeot-Leclercq, M.P.; Van Bambeke, F. Targeting the Type Three Secretion System in Pseudomonas aeruginosa. Trends Pharmacol. Sci. 2016, 37, 734-749. [CrossRef] [PubMed]

122. Hall, S.; McDermott, C.; Anoopkumar-Dukie, S.; McFarland, A.J.; Forbes, A.; Perkins, A.V.; Davey, A.K.; Chess-Williams, R.; Kiefel, M.J.; Arora, D.; et al. Cellular Effects of Pyocyanin, a Secreted Virulence Factor of Pseudomonas aeruginosa. Toxins 2016, 8, 236. [CrossRef]

123. Zeng, B.; Wang, C.; Zhang, P.; Guo, Z.; Chen, L.; Duan, K. Heat Shock Protein DnaJ in Pseudomonas aeruginosa Affects Biofilm Formation via Pyocyanin Production. Microorganisms 2020, 8, 395. [CrossRef] [PubMed]

124. Manago, A.; Becker, K.A.; Carpinteiro, A.; Wilker, B.; Soddemann, M.; Seitz, A.P.; Edwards, M.J.; Grassme, H.; Szabo, I.; Gulbins, E. Pseudomonas aeruginosa pyocyanin induces neutrophil death via mitochondrial reactive oxygen species and mitochondrial acid sphingomyelinase. Antioxid. Redox. Signal. 2015, 22, 1097-1110. [CrossRef] [PubMed]

125. Dauner, M.; Skerra, A. Scavenging Bacterial Siderophores with Engineered Lipocalin Proteins as an Alternative Antimicrobial Strategy. Chembiochem 2020, 21, 601-606. [CrossRef]

126. Cornelis, P.; Dingemans, J. Pseudomonas aeruginosa adapts its iron uptake strategies in function of the type of infections. Front. Cell Infect. Microbiol. 2013, 3, 75. [CrossRef] [PubMed]

127. Bonneau, A.; Roche, B.; Schalk, I.J. Iron acquisition in Pseudomonas aeruginosa by the siderophore pyoverdine: An intricate interacting network including periplasmic and membrane proteins. Sci. Rep. 2020, 10, 120. [CrossRef] [PubMed] 
128. Kang, D.; Kirienko, N.V. Interdependence between iron acquisition and biofilm formation in Pseudomonas aeruginosa. J. Microbiol. 2018, 56, 449-457. [CrossRef]

129. Cornelis, P.; Matthijs, S.; Van Oeffelen, L. Iron uptake regulation in Pseudomonas aeruginosa. Biometals 2009, 22, 15-22. [CrossRef]

130. Breidenstein, E.B.; de la Fuente-Nunez, C.; Hancock, R.E. Pseudomonas aeruginosa: All roads lead to resistance. Trends Microbiol. 2011, 19, 419-426. [CrossRef]

131. Poole, K. Outer membranes and efflux: The path to multidrug resistance in Gram-negative bacteria. Curr. Pharm. Biotechnol. 2002, 3, 77-98. [CrossRef] [PubMed]

132. Fajardo, A.; Martinez-Martin, N.; Mercadillo, M.; Galan, J.C.; Ghysels, B.; Matthijs, S.; Cornelis, P.; Wiehlmann, L.; Tummler, B.; Baquero, F.; et al. The neglected intrinsic resistome of bacterial pathogens. PLoS ONE 2008, 3, e1619. [CrossRef] [PubMed]

133. Vakulenko, S.B.; Mobashery, S. Versatility of aminoglycosides and prospects for their future. Clin. Microbiol. Rev. 2003, 16, 430-450. [CrossRef]

134. Chegini, Z.; Khoshbayan, A.; Taati Moghadam, M.; Farahani, I.; Jazireian, P.; Shariati, A. Bacteriophage therapy against Pseudomonas aeruginosa biofilms: A review. Ann. Clin. Microbiol. Antimicrob. 2020, 19, 45. [CrossRef]

135. Jamal, M.; Ahmad, W.; Andleeb, S.; Jalil, F.; Imran, M.; Nawaz, M.A.; Hussain, T.; Ali, M.; Rafiq, M.; Kamil, M.A. Bacterial biofilm and associated infections. J. Chin. Med. Assoc. 2018, 81, 7-11. [CrossRef]

136. Delcaru, C.; Alexandru, I.; Podgoreanu, P.; Grosu, M.; Stavropoulos, E.; Chifiriuc, M.C.; Lazar, V. Microbial Biofilms in Urinary Tract Infections and Prostatitis: Etiology, Pathogenicity, and Combating strategies. Pathogens 2016, 5, 65. [CrossRef]

137. Maurice, N.M.; Bedi, B.; Sadikot, R.T. Pseudomonas aeruginosa Biofilms: Host Response and Clinical Implications in Lung Infections. Am. J. Respir. Cell Mol. Biol. 2018, 58, 428-439. [CrossRef]

138. Rasamiravaka, T.; Labtani, Q.; Duez, P.; El Jaziri, M. The formation of biofilms by Pseudomonas aeruginosa: A review of the natural and synthetic compounds interfering with control mechanisms. Biomed. Res. Int. 2015, 2015, 759348. [CrossRef]

139. Koo, H.; Yamada, K.M. Dynamic cell-matrix interactions modulate microbial biofilm and tissue 3D microenvironments. Curr. Opin. Cell Biol. 2016, 42, 102-112. [CrossRef]

140. Hajishengallis, G.; Hajishengallis, E.; Kajikawa, T.; Wang, B.; Yancopoulou, D.; Ricklin, D.; Lambris, J.D. Complement inhibition in pre-clinical models of periodontitis and prospects for clinical application. Semin. Immunol. 2016, 28, 285-291. [CrossRef]

141. Watters, C.; Everett, J.A.; Haley, C.; Clinton, A.; Rumbaugh, K.P. Insulin treatment modulates the host immune system to enhance Pseudomonas aeruginosa wound biofilms. Infect. Immun. 2014, 82, 92-100. [CrossRef] [PubMed]

142. Maliniak, M.L.; Stecenko, A.A.; McCarty, N.A. A longitudinal analysis of chronic MRSA and Pseudomonas aeruginosa co-infection in cystic fibrosis: A single-center study. J. Cyst. Fibros. 2016, 15, 350-356. [CrossRef] [PubMed]

143. Reffuveille, F.; Fuente-Nunez Cde, L.; Fairfull-Smith, K.E.; Hancock, R.E. Potentiation of ciprofloxacin action against Gramnegative bacterial biofilms by a nitroxide. Pathog. Dis. 2015, 73, ftv016. [CrossRef]

144. Diaz, M.A.; Gonzalez, S.N.; Alberto, M.R.; Arena, M.E. Human probiotic bacteria attenuate Pseudomonas aeruginosa biofilm and virulence by quorum-sensing inhibition. Biofouling 2020, 36, 597-609. [CrossRef]

145. Idowu, T.; Zhanel, G.G.; Schweizer, F. A Dimer, but Not Monomer, of Tobramycin Potentiates Ceftolozane against MultidrugResistant and Extensively Drug-Resistant Pseudomonas aeruginosa and Delays Resistance Development. Antimicrob. Agents Chemother. 2020, 64, e02055-19. [CrossRef] [PubMed]

146. Sarshar, M.; Behzadi, P.; Ambrosi, C.; Zagaglia, C.; Palamara, A.T.; Scribano, D. FimH and Anti-Adhesive Therapeutics: A Disarming Strategy Against Uropathogens. Antibiotics 2020, 9, 397. [CrossRef]

147. Forti, F.; Roach, D.R.; Cafora, M.; Pasini, M.E.; Horner, D.S.; Fiscarelli, E.V.; Rossitto, M.; Cariani, L.; Briani, F.; Debarbieux, L.; et al. Design of a Broad-Range Bacteriophage Cocktail That Reduces Pseudomonas aeruginosa Biofilms and Treats Acute Infections in Two Animal Models. Antimicrob. Agents Chemother. 2018, 62, e02573-17. [CrossRef]

148. Waters, E.M.; Neill, D.R.; Kaman, B.; Sahota, J.S.; Clokie, M.R.J.; Winstanley, C.; Kadioglu, A. Phage therapy is highly effective against chronic lung infections with Pseudomonas aeruginosa. Thorax 2017, 72, 666-667. [CrossRef]

149. Sharma, G.; Rao, S.; Bansal, A.; Dang, S.; Gupta, S.; Gabrani, R. Pseudomonas aeruginosa biofilm: Potential therapeutic targets. Biologicals 2014, 42, 1-7. [CrossRef]

150. Masak, J.; Cejkova, A.; Schreiberova, O.; Rezanka, T. Pseudomonas biofilms: Possibilities of their control. FEMS Microbiol. 2014, 89, 1-14. [CrossRef]

151. Olson, M.E.; Harmon, B.G.; Kollef, M.H. Silver-coated endotracheal tubes associated with reduced bacterial burden in the lungs of mechanically ventilated dogs. Chest 2002, 121, 863-870. [CrossRef] [PubMed]

152. Kollef, M.H.; Afessa, B.; Anzueto, A.; Veremakis, C.; Kerr, K.M.; Margolis, B.D.; Craven, D.E.; Roberts, P.R.; Arroliga, A.C.; Hubmayr, R.D.; et al. Silver-coated endotracheal tubes and incidence of ventilator-associated pneumonia: The NASCENT randomized trial. JAMA 2008, 300, 805-813. [CrossRef]

153. Oliveira, V.C.; Macedo, A.P.; Melo, L.D.R.; Santos, S.B.; Hermann, P.R.S.; Silva-Lovato, C.H.; Paranhos, H.F.O.; Andrade, D.; Watanabe, E. Bacteriophage Cocktail-Mediated Inhibition of Pseudomonas aeruginosa Biofilm on Endotracheal Tube Surface. Antibiotics 2021, 10, 78. [CrossRef] [PubMed]

154. Hentzer, M.; Wu, H.; Andersen, J.B.; Riedel, K.; Rasmussen, T.B.; Bagge, N.; Kumar, N.; Schembri, M.A.; Song, Z.; Kristoffersen, P.; et al. Attenuation of Pseudomonas aeruginosa virulence by quorum sensing inhibitors. EMBO J. 2003, 22, 3803-3815. [CrossRef] [PubMed] 
155. Wu, H.; Song, Z.; Hentzer, M.; Andersen, J.B.; Molin, S.; Givskov, M.; Hoiby, N. Synthetic furanones inhibit quorum-sensing and enhance bacterial clearance in Pseudomonas aeruginosa lung infection in mice. J. Antimicrob. Chemother. 2004, 53, $1054-1061$. [CrossRef]

156. Muh, U.; Schuster, M.; Heim, R.; Singh, A.; Olson, E.R.; Greenberg, E.P. Novel Pseudomonas aeruginosa quorum-sensing inhibitors identified in an ultra-high-throughput screen. Antimicrob. Agents Chemother. 2006, 50, 3674-3679. [CrossRef]

157. Yang, L.; Rybtke, M.T.; Jakobsen, T.H.; Hentzer, M.; Bjarnsholt, T.; Givskov, M.; Tolker-Nielsen, T. Computer-aided identification of recognized drugs as Pseudomonas aeruginosa quorum-sensing inhibitors. Antimicrob. Agents Chemother. 2009, 53, $2432-2443$. [CrossRef]

158. Bjarnsholt, T.; Jensen, P.O.; Rasmussen, T.B.; Christophersen, L.; Calum, H.; Hentzer, M.; Hougen, H.P.; Rygaard, J.; Moser, C.; Eberl, L.; et al. Garlic blocks quorum sensing and promotes rapid clearing of pulmonary Pseudomonas aeruginosa infections. Microbiology 2005, 151, 3873-3880. [CrossRef]

159. Jakobsen, T.H.; van Gennip, M.; Phipps, R.K.; Shanmugham, M.S.; Christensen, L.D.; Alhede, M.; Skindersoe, M.E.; Rasmussen, T.B.; Friedrich, K.; Uthe, F.; et al. Ajoene, a sulfur-rich molecule from garlic, inhibits genes controlled by quorum sensing. Antimicrob. Agents Chemother. 2012, 56, 2314-2325. [CrossRef]

160. Smyth, A.R.; Cifelli, P.M.; Ortori, C.A.; Righetti, K.; Lewis, S.; Erskine, P.; Holland, E.D.; Givskov, M.; Williams, P.; Camara, M.; et al. Garlic as an inhibitor of Pseudomonas aeruginosa quorum sensing in cystic fibrosis-a pilot randomized controlled trial. Pediatr. Pulmonol. 2010, 45, 356-362. [CrossRef]

161. Rasmussen, T.B.; Skindersoe, M.E.; Bjarnsholt, T.; Phipps, R.K.; Christensen, K.B.; Jensen, P.O.; Andersen, J.B.; Koch, B.; Larsen, T.O.; Hentzer, M.; et al. Identity and effects of quorum-sensing inhibitors produced by Penicillium species. Microbiology 2005, 151, 1325-1340. [CrossRef] [PubMed]

162. Jakobsen, T.H.; Bragason, S.K.; Phipps, R.K.; Christensen, L.D.; van Gennip, M.; Alhede, M.; Skindersoe, M.; Larsen, T.O.; Hoiby, N.; Bjarnsholt, T.; et al. Food as a source for quorum sensing inhibitors: Iberin from horseradish revealed as a quorum sensing inhibitor of Pseudomonas aeruginosa. Appl. Environ. Microbiol. 2012, 78, 2410-2421. [CrossRef] [PubMed]

163. Zhou, L.; Zheng, H.; Tang, Y.; Yu, W.; Gong, Q. Eugenol inhibits quorum sensing at sub-inhibitory concentrations. Biotechnol. Lett. 2013, 35, 631-637. [CrossRef]

164. Chua, S.L.; Yam, J.K.; Hao, P.; Adav, S.S.; Salido, M.M.; Liu, Y.; Givskov, M.; Sze, S.K.; Tolker-Nielsen, T.; Yang, L. Selective labelling and eradication of antibiotic-tolerant bacterial populations in Pseudomonas aeruginosa biofilms. Nat. Commun. 2016, 7, 10750. [CrossRef] [PubMed]

165. Tateda, K.; Comte, R.; Pechere, J.C.; Kohler, T.; Yamaguchi, K.; Van Delden, C. Azithromycin inhibits quorum sensing in Pseudomonas aeruginosa. Antimicrob. Agents Chemother. 2001, 45, 1930-1933. [CrossRef] [PubMed]

166. Tsai, W.C.; Rodriguez, M.L.; Young, K.S.; Deng, J.C.; Thannickal, V.J.; Tateda, K.; Hershenson, M.B.; Standiford, T.J. Azithromycin blocks neutrophil recruitment in Pseudomonas endobronchial infection. Am. J. Respir. Crit. Care Med. 2004, 170, 1331-1339. [CrossRef]

167. Saiman, L.; Marshall, B.C.; Mayer-Hamblett, N.; Burns, J.L.; Quittner, A.L.; Cibene, D.A.; Coquillette, S.; Fieberg, A.Y.; Accurso, F.J.; Campbell, P.W., 3rd; et al. Azithromycin in patients with cystic fibrosis chronically infected with Pseudomonas aeruginosa: A randomized controlled trial. JAMA 2003, 290, 1749-1756. [CrossRef]

168. Bzdrenga, J.; Daude, D.; Remy, B.; Jacquet, P.; Plener, L.; Elias, M.; Chabriere, E. Biotechnological applications of quorum quenching enzymes. Chem. Biol. Interact. 2017, 267, 104-115. [CrossRef]

169. Bijtenhoorn, P.; Mayerhofer, H.; Muller-Dieckmann, J.; Utpatel, C.; Schipper, C.; Hornung, C.; Szesny, M.; Grond, S.; Thurmer A.; Brzuszkiewicz, E.; et al. A novel metagenomic short-chain dehydrogenase/reductase attenuates Pseudomonas aeruginosa biofilm formation and virulence on Caenorhabditis elegans. PLOS ONE 2011, 6, e26278. [CrossRef]

170. Lin, Y.H.; Xu, J.L.; Hu, J.; Wang, L.H.; Ong, S.L.; Leadbetter, J.R.; Zhang, L.H. Acyl-homoserine lactone acylase from Ralstonia strain XJ12B represents a novel and potent class of quorum-quenching enzymes. Mol. Microbiol. 2003, 47, 849-860. [CrossRef]

171. Sio, C.F.; Otten, L.G.; Cool, R.H.; Diggle, S.P.; Braun, P.G.; Bos, R.; Daykin, M.; Camara, M.; Williams, P.; Quax, W.J. Quorum quenching by an N-acyl-homoserine lactone acylase from Pseudomonas aeruginosa PAO1. Infect. Immun. 2006, 74, 1673-1682. [CrossRef] [PubMed]

172. Chun, C.K.; Ozer, E.A.; Welsh, M.J.; Zabner, J.; Greenberg, E.P. Inactivation of a Pseudomonas aeruginosa quorum-sensing signal by human airway epithelia. Proc. Natl. Acad. Sci. USA 2004, 101, 3587-3590. [CrossRef]

173. Stoltz, D.A.; Ozer, E.A.; Ng, C.J.; Yu, J.M.; Reddy, S.T.; Lusis, A.J.; Bourquard, N.; Parsek, M.R.; Zabner, J.; Shih, D.M. Paraoxonase2 deficiency enhances Pseudomonas aeruginosa quorum sensing in murine tracheal epithelia. Am. J. Physiol. Lung Cell Mol. Physiol. 2007, 292, L852-L860. [CrossRef] [PubMed]

174. Devarajan, A.; Bourquard, N.; Grijalva, V.R.; Gao, F.; Ganapathy, E.; Verma, J.; Reddy, S.T. Role of PON2 in innate immune response in an acute infection model. Mol. Genet. Metab. 2013, 110, 362-370. [CrossRef]

175. Griffin, P.E.; Roddam, L.F.; Belessis, Y.C.; Strachan, R.; Beggs, S.; Jaffe, A.; Cooley, M.A. Expression of PPARgamma and paraoxonase 2 correlated with Pseudomonas aeruginosa infection in cystic fibrosis. PLoS ONE 2012, 7, e42241. [CrossRef]

176. Bedi, B.; Maurice, N.M.; Ciavatta, V.T.; Lynn, K.S.; Yuan, Z.; Molina, S.A.; Joo, M.; Tyor, W.R.; Goldberg, J.B.; Koval, M.; et al. Peroxisome proliferator-activated receptor-gamma agonists attenuate biofilm formation by Pseudomonas aeruginosa. FASEB 2017, 31, 3608-3621. [CrossRef] 
177. Bedi, B.; Yuan, Z.; Joo, M.; Zughaier, S.M.; Goldberg, J.B.; Arbiser, J.L.; Hart, C.M.; Sadikot, R.T. Enhanced Clearance of Pseudomonas aeruginosa by Peroxisome Proliferator-Activated Receptor Gamma. Infect. Immun. 2016, 84, 1975-1985. [CrossRef]

178. Christensen, L.D.; van Gennip, M.; Rybtke, M.T.; Wu, H.; Chiang, W.C.; Alhede, M.; Hoiby, N.; Nielsen, T.E.; Givskov, M.; Tolker-Nielsen, T. Clearance of Pseudomonas aeruginosa foreign-body biofilm infections through reduction of the cyclic Di-GMP level in the bacteria. Infect. Immun. 2013, 81, 2705-2713. [CrossRef]

179. Groizeleau, J.; Rybtke, M.; Andersen, J.B.; Berthelsen, J.; Liu, Y.; Yang, L.; Nielsen, T.E.; Kaever, V.; Givskov, M.; Tolker-Nielsen, T. The anti-cancerous drug doxorubicin decreases the c-di-GMP content in Pseudomonas aeruginosa but promotes biofilm formation. Microbiology 2016, 162, 1797-1807. [CrossRef]

180. Pletzer, D.; Hancock, R.E. Antibiofilm Peptides: Potential as Broad-Spectrum Agents. J. Bacteriol. 2016, 198, 2572-2578. [CrossRef]

181. Overhage, J.; Campisano, A.; Bains, M.; Torfs, E.C.; Rehm, B.H.; Hancock, R.E. Human host defense peptide LL-37 prevents bacterial biofilm formation. Infect. Immun. 2008, 76, 4176-4182. [CrossRef]

182. Ebbensgaard, A.; Mordhorst, H.; Overgaard, M.T.; Nielsen, C.G.; Aarestrup, F.M.; Hansen, E.B. Comparative Evaluation of the Antimicrobial Activity of Different Antimicrobial Peptides against a Range of Pathogenic Bacteria. PLoS ONE 2015, 10, e0144611. [CrossRef] [PubMed]

183. Dosunmu, E.F.; Emeh, R.O.; Dixit, S.; Bakeer, M.K.; Coats, M.T.; Owen, D.R.; Pillai, S.R.; Singh, S.R.; Dennis, V.A. The antimicrobial peptide TP359 attenuates inflammation in human lung cells infected with Pseudomonas aeruginosa via TLR5 and MAPK pathways. PLoS ONE 2017, 12, e0176640. [CrossRef] [PubMed]

184. de la Fuente-Nunez, C.; Reffuveille, F.; Mansour, S.C.; Reckseidler-Zenteno, S.L.; Hernandez, D.; Brackman, G.; Coenye, T.; Hancock, R.E. D-enantiomeric peptides that eradicate wild-type and multidrug-resistant biofilms and protect against lethal Pseudomonas aeruginosa infections. Chem. Biol. 2015, 22, 196-205. [CrossRef] [PubMed] 